УДК 339.7:[336.76:334.7(1-194)]](045)

DOI: https://doi.org/10.37320/2415-3583/18.3

Фенюк Я.К.

аспірант кафедри економічної політики та врядування Національна академія державного управління при Президентові Украӥни

\title{
ГЛОБАЛЬНА ОФШОРИЗАЦІЯ ЯК ВАРТІСТЬ БОРОТЬБИ ЗА МІЖНАРОДНУ КОНКУРЕНТОЗДАТНІСТЬ ФІНАНСОВОГО РИНКУ
}

У статті розглянуто особливості становлення та формування міжснародних фінансових иеетрів. Зосереджено увагу на ролі, яку відіграють офшорні юрисдикиї у світовій фінансовій системі. Досліджено питання необхідності регулювання офшорної діяльності, в основу покладаючи міжнародний досвід $і$ наднаціональний рівень співробітництва та контролю. Розглянуто економічний процес відтоку капіталу та безпосередньо його вплив, обсяги та наслідки для міжнародних фінансових ринків. Визначено, щзо боротьба за конкурентоздатність внутрішнього фінансового ринку є одним із ключових мотивів, щяо породжує масштабність та привабливість існування офшорних иентрів $i$, як наслідок, маніпулювання та використання різноманітних схем мінімізації оподаткування та виведення капіталу за межі його походження. Зроблено висновки та пропозиції, щзо саме міжнародне співробітництво та практична імплементація світових рекомендацій (план ВЕРS) здатні знизити привабливість офшорних фінансових цеентрів і подальший відтік капіталу в напрямі низько податкових гаваней.

Ключові слова: міжнародний фінансовий иентр, фінансові ринки, офшорна юрисдикція, офшорна зона, податкова гавань, план BEPS, виведення капіталів, міжнародна конкурентоспроможність.

Постановка проблеми. Деофшоризація $є$ загальносвітовою тенденцією, а виклики та завдання, що стоять перед урядами країн щодо зниження обсягів відтоку капіталу, не є питаннями внутрішньої політики окремої держави, а давно знаходяться у площині міжнародного регулювання та співробітництва. Неконтрольоване виведення бізнес-структурами капіталу за межі країни походження, легалізація їхніх незаконних прибутків через офшори нині визнаються однією 3 ключових загроз фінансовій безпеці країн із відкритою економікою. Офшорні зони та податкові гавані, що створювалися задля підтримки світової конкуренції та надання вільного доступу на міжнародний фінансовий ринок, нині на тому боці глобалізаційних процесів, який потребує наднаціонального контролю та відповідальності.

Автор зазначає, що регулюванню офшорних зон притаманна певна відокремленість на тому чи іншому аспекті діяльності компаній, а в цій сфері необхідна концентрація та формування єдиної наднаціональної системи протидії та міжнародної кооперації. Затверджений OECР у 2013 р. план дій BEPS (Base Erosion and Profit Shifting), що передбачає впровадження країнами переліку заходів щодо протидії розмиванню податкової бази та виведенню прибутку [6], сьогодні є центральним документом антиофшорної політики світових країн-лідерів. Україна також приєдналася до програми розширеного співробітництва 3 питань імплементації плану протидії, тому в статті зосереджено увагу на питаннях та викликах, що виникають у процесі впровадження плану BEPS. Однозначна та безумовна імплементація потребує проведення попереднього аналізу внутрішньої політики країни, так званої індивідуалізації, задля забезпечення мінімальної «гравітації» ринку та всіх його учасників. На етапі впровадження плану дій у систему контролю та моніторингу України виникають питання, що можна трактувати двозначно та які потребують додаткового вивчення.

Аналіз останніх досліджень і публікацій. Аналіз стану розроблення із цієї проблематики свідчить, 
що питання регулювання офшорної діяльності потребує детального й уніфікованого визначення основних понять та напрямів взаємодії держави та приватного сектору, що є ключовими фігурами процесу регулювання економіки у цілому, та безпосередньо фінансової сфери, що є частиною міжнародного фінансового ринку та міжнародної системи регулювання. Проблемам регулювання, становлення та функціонування офшорних фінансових центрів присвячено дослідження В.А. Вергуна [2], В.М. Геєця, О.О. Манзюк [1], В.А. Предборського [13], А.С. Філіпенка [12]. Закордонними вченими, що займалися цією науковою тематикою, є Е. Шамбост, М.А. Янг [14] та інші науковці. Ураховуючи їхні досягнення, відзначимо, що у світовій глобалізованій економіці офшоризація швидко трансформується і приймає оновлені характеристики, 3'являються нові явища і тенденції, що потребують подальшого розроблення.

Автор звертається до вивчення діяльності міжнародних організацій у сфері антиофшорної політики, таких як Міжнародний валютний фонд (МВФ), Організація економічного співробітництва та розвитку (ОЕСР), Міжнародна група 3 протидії відмиванню брудних грошей (ФАТФ), Міжнародний валютний фонд (МВФ) та «Велика двадцятка» (G20).

Мета статті полягає у з'ясуванні на основі аналізу та узагальнення світового досвіду етапів становлення та розвитку міжнародних фінансових центрів, в основі формування яких лежить мета підвищення конкурентоспроможність національного фінансового ринку; визначенні ролі офшорних центрів у системі міжнародних фінансів, особливостей їх функціонування та впливу на подальший розвиток світової фінансової кооперації; розгляді основних напрямів та можливостей регулювання міжнародного руху капіталу і безпосередньо офшорних компаній у процесі формування фінансового ринку України.

Виклад основного матеріалу. Протягом усієї світової історії ключовими національними інтересами держави є захист суверенітету, забезпечення безпеки та сталого розвитку, що можливо досягти за умови високої конкурентоздатності економіки. Надання пільгового режиму оподаткування стало для низки країн стратегією розвитку своїх фінансових ринків та підвищення конкурентоздатності економіки. Виникнення та розвиток офшорних зон, податкових гаваней перетворилися на один із двигунів процесу глобалізації через можливість проведення оптимізації, найчастіше агресивного ухилення та мінімізації оподаткування. Проте з часом, у міру зростання ступеня фінансово-економічної взаємозалежності діяльність офшорних зон почала зосереджувати на собі все більшу увагу держав та міжнародних організацій. Питання необхідності регулювання офшорного бізнесу пов'язане з тим, що офшорна діяльність вийшла далеко за межі внутрішніх ринків та рухається в напрямі подальшої глобалізації і безумовного проникнення у всі сфери економічної діяльності країни.

Програми вдосконалення конкурентоздатності національних фінансових ринків можуть формуватися як у країнах, що вже мають сталий та розвинутий ринок, так і в країнах, де тільки зароджується та починається формування міжнародних фінансових центрів (далі - МФЦ). Багаточисельні дослідження існуючих сьогодні МФЦ із погляду стратегічних цілей завдань розвитку можна умовно поділити на дві групи: «традиційні» МФЦ та «офшорні» МФЦ. Традиційні - це ті фінансові центри, що розвиваються на базі достатньо великого та системно сформованого внутрішнього фінансового ринку. Важливо зазначити, що державна підтримка та певний контроль націлені на результат формування сильного ринку, збалансування «гравітаційних» моментів у процесі становлення ринку (концентрації інвестиційного попиту та фінансових послуг).

Фінансові центри, регулювання яких відрізняється від національного, що мають інститути резидентства та спеціального управління, котрі володіють додатковими податковими та іншими пільгами для резидентів МФЦ, найчастіше i визначаються офшорними центрами. Як правило, вони орієнтовані на залучення іноземних інвесторів, реципієнтів інвестицій та фінансових організацій переважно шляхом надання податкових пільг. Такі пільги, як створення умов для мінімізації оподаткування, максимальна лібералізація доступу, високий рівень захисту інвестора, надають максимально зручне та безпечне середовище для функціонування фінансових організацій. Особливою та відмінною рисою так званих офшорних юрисдикцій, що розвиваються на базі державної програми, є існування спеціальних державних агентств, що управляють МФЦ. Існування таких агентств викликано потребою виконання низки квазідержавних функцій, до них можна віднести: реєстрацію фінансових організацій як резидента МФЦ, управління інфраструктурними організаціями, інформаційне супроводження, захист даних, надання послуг соціальної інфраструктури (транспорт, кадри, аутсорсинг і т. д.), реєстрацію прав власності та інші додаткові послуги.

Більшість існуючих МФЦ та держав, що мають на меті формування фінансового центру на базі свого національного ринку, використовують традиційну модель: Лондон, Нью-Йорк, Токіо, Швейцарія та Німеччина, цілісно як країни. Прикладами великих офшорних центрів є Сінгапур, Дубай, а от Гонконг - це проміжна модель, побудована на ознаках як традиційного, так і офшорного фінансового центру.

Дану статтю присвячено офшорним центрам. Існує багато визначень та не має єдиного терміна, що визначав би сутність та чіткі ознаки офшорної компанії, офшорної юрисдикції, центру або податкової гавані. Міжнародна спільнота переважно використовує поняття «офшорний фінансовий центр», ОЕСР трактує даний термін так: це країни або юрисдикції з фінансовими центрами, що містять фінансові установи, які мають справу переважно з нерезидентами та/або в іноземній валюті в масштабі, не пропорційному розміру приймаючої економіки. Контрольовані компанії чи ті, де власники - нерезиденти, відіграють значну роль у центрі. Установи у центрі цілком можуть отримати вигоду від податкових пільг, недоступних для тих, хто знаходиться поза центром [3]. На думку автора, найкраще сутність конкретного терміна можна розкрити через його ознаки та особливості. Основними ознаками, що притаманні офшорним центрам, є можливість суттєвого зниження тягаря оподаткування та інших 
додаткових платежів; комфортне правове середовище для організації та ведення бізнесу, що передбачає спрощені умови адміністративного та фінансового нагляду; анонімність у проведенні фінансових операцій та кінцевих бенефіціарів офшорних компаній. Головною особливістю офшорної зони є те, що зареєстровані компанії не мають права вести на іiї території підприємницьку діяльність. Таким чином, під офшорним цеентром автор розуміє країни та території, щчо надають пільговий податковий режим зареєстрованим іноземним компаніям, які не ведуть діяльність на території країни реєстрації.

Із цих ознак і випливають основні мотиви, через які офшорні центри мають таку популярність та стають зі зворотного боку медалі глобалізаційних процесів. Передусім це агресивне податкове планування та оптимізація податкового навантаження; важливо зазначити, що ці можливості відкрили перед транснаціональними компаніями (далі - ТНК), інструмент значного зниження свого податкового тягаря. В офшорах концентруються трейдери, котрі стають центрами концентрації прибутку. Варто зауважити, що такі структури створюються не лише приватними компаніями, а й бізнес-структурами, де контрольним пакетом акцій володіє держава. Захист власності та доходів від політичних ризиків, захист від потенційної націоналізації, необгрунтованих податкових претензій, криміналізації економіки та корумпованості влади. Приховування інформації щодо дійсних учасників угоди в поєднанні 3 можливою податковою оптимізацією та іншими традиційними зручностями офшорного володіння власністю. Інвестиції в країну походження капіталу, за допомогою інвестиційного інструменту частково вертаються раніше вивезені капітали у вигляді кредитів, таким чином «іноземні» інвестори намагаються захистити свої інвестиції за несприятливих для них обставин у міжнародних судах. Слід зробити акцент на криміналізованому інструменті, що $є$ вагомим у грошовому еквіваленті загальних обсягів виведених коштів через офшорні центри, це легалізація доходів, отриманих злочинним або незаконним шляхом. Оскільки офшори забезпечують високу конфіденційність, цей інструмент часто використовується у схемах відмивання коштів. Автор стверджує, що перелік інструментів, провокуючий користування офшорними послугами, значно ширший, у статті перелічено основні в абсолютному грошовому еквіваленті.

Нині податкові гавані охопили майже весь світ та обслуговують усі основні фінансові та комерційні центри. За даними некомерційної науково-дослідної організації Global Financial Integrity (GFI), останній звіт щодо незаконних фінансових потоків (Illict financial flows -IFF), в якому основна увага зосереджена на використанні інструменту трансфертного ціноутворення (Trade misinvoicing), опублікований у січні 2019 р. Варто звернути увагу, що міжнародні організації вбачають в даному інструменті один із системоформуючих для цілей виведення коштів 3-під оподаткування. Для того, щоб визначити імпорт/експорт країни, який, можливо, був неправильно виставлений, GFI проводить аналіз розриву вартості, вивчаючи дані, які щороку подаються урядами до бази даних Comtrade OOH, та застосовуючи низку фільтрів для забезпечення нерів- них торгів. Потім GFI використовує аналіз країн-партнерів для порівняння та протиставлення відмінностей між будь-яким набором двох країн, щоб виявити розриви у вартості або невідповідність у звітних даних. Цифри дослідження за 2015 р. визначають, що за обсягами незаконного відтоку капіталу лідирують європейські держави Угорщина (7,6 млрд дол.), Румунія (5,1 млрд дол.) і Болгарія (1,8 млрд дол.) разом із країнами Латинської Америки. За рейтингом незаконного надходження доларів входить регіонально різноманітна група країн, включаючи Польщу (32,3 млрд дол.), Румунію (6,8 млрд дол.), Індонезію (10,1 млрд дол.) та Бангладеш (2,8 млрд дол.) [4]. В абсолютних значеннях обсяги коштів в офшорних центрах зростають: із 6 трлн дол. США у 2005 р. до 10 трлн дол. США у 2018 p. [5].

Без сумніву, настільки значна концентрація коштів на рахунках в офшорних юрисдикціях - це наслідок систематичного ухилення від сплати податків, що, безумовно, призводить до зростання міжнародної фінансової нестабільності. Варто зауважити, що найбільш відчутними прямими наслідками процесів виведення капіталів, окрім недоотримання бюджетом податкових надходжень, є недобросовісна податкова конкуренція; акумуляція в офшорних зонах великих обсягів спекулятивного капіталу; зростання можливостей для тінізації економіки та всі умови для прямого відтоку капіталу з країни його походження.

За таких реалій перші спроби деофшоризації почали проводитися ще в 1990-х роках, а от дійсне масштабування боротьби проти виведення капіталу розпочалося в період міжнародної фінансової кризи 2008-2009 рр. Сьогодні основоположним документом у сфері антиофшорної політики є план BEPS (Base erosion and Profit Shifting) - проєкт ОЕСР із розроблення заходів протидії розмиванню податкової бази та виведенню прибутку [6]. Даний план включає аналіз незаконних схем, які використовуються платниками податків, заходи протидії виведення податкової бази в низькоподаткові юрисдикції, а також рекомендації, спрямовані на проведення реформ у цілях уніфікації податкового законодавства країн. За оцінками ОЕСР, утрати бюджетів країн світу від агресивного податкового планування, що грунтується на розмиванні бази оподаткування i переміщенні прибутків за кордон, щороку сягають 100-240 млрд дол. США, або 4-10\% сукупних надходжень прибутку від податку на прибуток підприємств. При цьому бюджети країн, що розвиваються, втрачають більше, ніж бюджети розвинених країн [11].

На сучасному етапі в Україні продовжуються трансформаційні процеси, які спрямовані на розвиток ринкової економічної системи, що зумовлює необхідність активної регулюючої ролі держави. Чисельними науковими дослідженнями у сфері державного управління доведено, що у країнах із трансформаційною економікою необхідність державного регулювання проявляється більшою мірою, оскільки самоорганізація (а ринок є класичним зразком самоорганізації) властива досить стійким системам і малоефективна в період переходу від однієї системи до іншої, враховуючи також і той факт, що трансформаційні процеси ускладнюються загостренням соціальних проблем, які мають бути пом'якшені. Україна не є винятком та 
як держава із суттєвим фіскальним навантаженням та непрогнозованим державним регулюванням кожного дня стикається зі значними обсягами відтоку капіталу. Додатково, беручи до уваги реалії економіко-політичної ситуації в Україні, макроекономічну нестабільність, недосконалість системи оподаткування, відсутність інституційних механізмів захисту прав власності, волантильність та низьку ліквідність фінансових ринків, не дивно, що близько 80\% інвестицій в Україну зроблено українцями через офшорні компанії.

Найпоширенішими схемами виведення капіталів, згідно 3 даними Держфінмоніторингу, $\epsilon$ такі: заниження ціни на експортовані товари; завищення ціни на імпортовані товари; фальшиві імпортні контракти, фіктивні кредитні угоди; непрямі експортні контракти; оплата консалтингових послуг та виплата грошей за використання прав інтелектуальної власності, кредитів, позик і т. д. Чинними документами, що визначають перелік, так званий «список», офшорних зон є Розпорядження КМУ № 143-р від 23.02.2011 «Про віднесення держав до переліку офшорних зон» [7] та Постанова КМУ № 1045 від 27.12.2017 «Про затвердження переліку держав (територій), які відповідають критеріям, установленим підпунктом 39.2.1.2 ПКУ» [8].

Аналізуючи статистичні дані Національного банку України (далі - НБУ), що тепер консолідує інформацію про зовнішньоекономічні операції та прямі інвестиції в/з України [9] та Державної служби статистики України [10], цифри підтверджують активність використання офшорних компаній для ведення бізнесу. Так от, 3 2015 по вересень 2018 р. Україна експортувала продукції п’яти найбільших товарних груп на 112 млрд дол. Із них 42 млрд дол. пішли в офшори. Потенційно це обсяг «схемного експорту» для ухилення від податків. Експорт в офшорні країни за 2017 р. становив понад 11 млрд дол. (близько 260 млрд грн). Цікавим $є$ факт, що одними 3 лідерів прямих інвестицій в Україну $є$ Кіпр, Люксембург, Швейцарія, Британські Віргінські Острови, Беліз та Панама, у загальному обсязі інвестицій у 2015-2019 рр. становлять 42\% незмінно, при цьому інвестиції з України (3540 млн дол.) у 2019 р. направлені не більше ніж у 10 країн світу, серед них більше 50\% припадає на Кіпр (1431 млн дол.), БВО (337 млн дол.) та Швейцарію (13,4 млн дол.). Цифри говорять самі за себе.

Як зазначалося вище, основний документ передбачає конкретні кроки та заходи для усунення прогалин у міжнародному податковому регулюванні і розбіжностей у національному податковому законодавстві різних країн, які уможливлюють «приховування» корпоративного прибутку та його штучне переміщення у низькоподаткові юрисдикції, де компанії не здійснюють економічної діяльності. Варто перелічити заходи, визначені ОЕСР, оскільки саме у цих сферах, куди спрямовані дії щодо посиленого контролю, спостерігаються найбільші прогалини в системі регулювання міжнародного руху капіталу та офшорної діяльності. Таким чином, захід 1 - вирішення податкових проблем «цифрової економіки»; захід 2 - нейтралізація наслідків гібридних податкових схем; захід 3 - розроблення ефективних правил стосовно контрольованих іноземних компаній (КІК); захід 4 - обмеження розмивання бази оподаткування шляхом вирахування з бази оподаткування відсотків та інших фінансових виплат; захід 5 - підвищення ефективності протидії шкідливим податковим практикам з урахуванням принципу прозорості та сутності; захід 6 - запобігання наданню пільг, передбачених угодами про уникнення подвійного оподаткування, за невідповідних обставин; захід 7 - запобігання штучному уникненню статусу постійного представництва; заходи 8-10 спрямовано на узгодження наслідків трансфертного ціноутворення зі створенням вартості: нематеріальні активи, ризики та капітал, операції з високим рівнем ризику; захід 11 - вимірювання та моніторинг BEPS; захід 12 - обов'язкові правила розкриття інформації; захід 13 - документація з трансфертного ціноутворення та звітність у розрізі країн; захід 14 - підвищення ефективності механізмів урегулювання спорів та останній захід 15 - розроблення багатостороннього інструменту для внесення змін до угод про уникнення подвійного оподаткування. Визначені кроки є базою для боротьби зі зменшенням масштабів потоку капіталу в напрямі зниження податкового тягаря, тому приєднання до плану й подальша ефективна і взаємовигідна кооперація можуть впровадити дійсні та результативні механізми та інструменти в систему регулювання міжнародних i національних офшорних фінансових центрів.

Висновки. Резюмуючи, можна чітко стверджувати, що необхідно створювати систему, що слугуватиме підгрунтям для незалежного функціонування інституцій публічного управління у сфері регулювання офшорної діяльності, та слідувати світовим практикам, що вказують на ефективний результат імплементації. Важливим фактом залишається момент збереження ідентичності та особливостей функціонування національного ринку, шлях «підтримання та створення», а не руйнації через механізми надмірного контролю та адміністративної відповідальності.

Автор наголошує, що саме держави-лідери відіграють ключову роль у боротьбі з податковими гаванями, безпосередньо від них залежить, чи залишаться офшори «чорними дірами» для виведення капіталу та відмивання коштів або ж стануть елементами механізму світової економіки, які націлені на підвищення міжнародної конкурентоздатності. Аналізуючи інструменти та важелі впливу на процеси регулювання офшорів, можна побачити високий рівень політизації, сфера лежить у площині лобізму інтересів ТНК. Йдеться про двосторонність офшорної політики, що проводиться розвинутими країнами світу: з одного боку, ОЕСР не має достатньо інструментів для протидії «шкідливим податковим практикам», а 3 іншого - багато членів об'єднання (Великобританія, Швейцарія, країни БЕНІЛЮКСу) самі визнаються як податкові гавані та історично пов'язані 3 діяльністю внутрішніх офшорних територій.

Для українських реалій необхідно забезпечити дієву систему не лише з боку регулювання, а й із боку заохочення щодо умов ведення бізнесу та нагромадження капіталів в Україні; створити інститут відповідальності для тих органів влади, що проводять політику в інвестиційній сфері та створюють передумови для конкурентного бізнес-середовища, за масштаби виведених коштів. Відповідальність повинна бути двох- 
сторонньою. Результатом упровадження проєкту BEPS має стати, окрім прямої протидії офшорній діяльності, поліпшення інвестиційного клімату в країні, що $є$ першим чинником повернення та акумулювання прибутків в Україні, і як довгострокова перспектива - трансфор- мація використання офшорів не як зон утримування прибутку, капіталів та прав власності на активи, а перехід їх у національну юрисдикцію та їх використання як певних майданчиків, націлених на завоювання висококонкурентних закордонних ринків.

\section{Список використаних джерел:}

1. Манзюк О.О. Механізм мінімізації негативного впливу офшорних юрисдикцій на розвиток національної економіки : автореф. дис. ... канд. екон. наук : 08.00.03 ; Центр. спілка спожив. т-в України, Львів. комерц. акад. Львів, 2015.21 с.

2. Вергун В.А., Ступницький О.І. Глобальний рівень регулювання практики створення і діяльності офшорних зон і територій. Проблемы развития внешнеэкономических связей и привлечения иностранных инвестиций: региональный аспект : сборник научных трудов / ред. Ю.В. Макогон и др. Донецк : ДНУ, 2012. С. 60-65.

3. OECD Glossary of statistical terms, offshore financial center : вебсайт. URL: https://stats.oecd.org/glossary/detail.asp?ID=5988 (дата звернення: 21.04.2021)/

4. Illicit Financial Flows to and from 148 Developing Countries: 2006-2015 // Global / Financial Integrity : вебсайт. URL: https://gfintegrity.org/report/2019-iff-update/ (дата звернення: 28.04.2021)/

5. Gabriel Zucman, Global Wealth Inequality. Annual Review of Economics. 2019. Vol. 11. P. 109-38. DOI: 10.1146/ANNUREVECONOMICS- 080218-025852. URL: https://gabriel-zucman.eu/files/Zucman2019.pdf (дата звернення: 28.04.2021).

6. Action plan on base erosion and profit shifting. OECD. 2013. URL: https:// www.oecd.org/ctp/BEPSActionPlan.pdf (дата звернення: 21.04.2021).

7. Розпорядження КМУ від 23 лютого 2011 р. № 143-р.

8. Постанова КМУ від 27 грудня 2017 р. № 1045.

9. Статистика зовнішнього сектору України. НБУ. 2021. URL: https://bank.gov.ua/ua/statistic/sector-external/data-sectorexternal\#1 (дата звернення: 03.04.2021).

10. Зовнішньоекономічна діяльність, статична інформація, ДСУ.

11. Загрядська М. Деофшоризація в Україні: змінюйтеся раніше, ніж вас змусять це зробити. Офіційно про податки. 2019. № 42(1042). URL: http://www.visnuk.com.ua/uk/publication/100015148-24-1 (дата звернення: 21.04.2021).

12. Філіпенко А.С. Міжнародні економічні відносини: історія : підручник. Київ : Либідь, 2006. 390 с.

13. Предборський В.А. Теоретичні аспекти тінізації економіки України в умовах трансформаційних процесів : автореф. дис. ... д-ра екон. наук : 08.00.03 ; НАН України, Н.-д. центр індустр. пробл. розв. Харків, 2011. 34 с.

14. Young M.A. Banking Secrecy and Offshore Financial Centers: Money Laundering and Offshore Banking. Oxon : Routledge, 2013. $178 \mathrm{p}$.

\section{References:}

1. Manzuk O.O. (2015) Mekhanizm minimizaciji neghatyvnogho vplyvu ofshornykh jurysdykcij na rozvytok nacionaljnoji ekonomiky [Mechanism for minimizing the negative impact of offshore jurisdictions on the development of the national economy] (PhD Thesis), Lviv.

2. Verghun V.A., Stupnycjkyj O.I. (2012) Globaljnyj rivenj reghuljuvannja praktyky stvorennja i dijaljnosti ofshornykh zon i terytorij [Global level of regulation of the practice of creation and operation of offshore zones and territories]. Development problems of foreign economic relations and attraction of foreign investments: regional aspect. Donetsk: DNU, pp. 60-65. (in Ukrainian)

3. OECD Glossary of statistical terms, offshore financial center. Available at: https://stats.oecd.org/glossary/detail.asp?ID=5988 (accessed 21 April 2021).

4. Illicit Financial Flows to and from 148 Developing Countries: 2006-2015. Global Financial Integrity. Available at: https://gfintegrity.org/report/2019-iff-update/ (accessed 28 April 2021).

5. Gabriel Zucman, Global Wealth Inequality, Annual Review of Economics. 2019. Vol. 11:109-38. DOI: 10.1146/ANNUREVECONOMICS- 080218-025852. Available at: https://gabriel-zucman.eu/files/Zucman2019.pdf (accessed 28 April 2021).

6. Action plan on base erosion and profit shifting. OECD. 2013. Available at: https:// www.oecd.org/ctp/BEPSActionPlan.pdf (accessed 21 April 2021).

7. Rozporyadzenya KMU vid 23.02.2011 N 143-p. [Directive of Cabinet of Ministers of Ukraine from 23.02.2011 \#143-p].

8. Postanova KMU vid 27.12.2017 № 1045. [Resolution of Cabinet of Ministers of Ukraine from 27.12.2017 \#1045].

9. National Bank of Ukraine (2021) Statystyka zovnishnjogho sektoru Ukrainy [Statistics of the external sector of Ukraine]. Kyiv: NBU. Available at: https://bank.gov.ua/ua/statistic/sector-external/data-sector-external\#1 (accessed 03 April 2021)

10. Derzhavna sluzhba statystyky Ukrainy (2020) Zovnishnoekonomichna Diialnist Statychna Informatsiia [Foreign Economic Activity, Static Information]. Kyiv: Informatsiino-analitychne ahentstvo.

11. Zahriadska M. (2019) Deofshoryzatsiia v Ukraini: zminiuitesia ranishe, nizh vas zmusiat tse zrobyty [Deoffshorization in Ukraine: change before you are forced to do so]. Visnyk ofitsiino pro podatky Derzhavnoi fiskalnoi sluzhby Ukrainy. Visnuk official about tax. Kyiv: DFSU, vol. 42 (1042). Available at: http://www.visnuk.com.ua/uk/publication/100015148-24-1 (accessed 21 April 2021).

12. Filipenko A.S. (2006) Mizhnarodni ekonomichni vidnosyny [International economic relations]. Kyiv: Lubid. (in Ukrainian)

13. Predborskyi V.A. (2011) Teoretychni aspekty tinizatsii ekonomiky Ukrainy $\mathrm{v}$ umovakh transformatsiinykh protsesiv [Theoretical shadow aspects of Ukraine's economy in the conditions of transformation processes] (PhD thesis), Kharkiv: NAN Ukrainy. (in Ukrainian)

14. Young M.A. (2013) Banking Secrecy and Offshore Financial Centers: Money Laundering and Offshore Banking/Mary Alice Young. Oxon: Routledge, 178 p. 
Feniuk Iana

National Academy for Public Administration Under the President of Ukraine

\section{GLOBAL OFFSHORIZATION AS THE COST OF THE STRUGGLE FOR INTERNATIONAL COMPETITIVENESS OF THE FINANCIAL MARKET}

The article considers the formation peculiarities of international financial centers. The focus is on the role what offshore jurisdictions play in the global financial system and the necessity for offshore activities regulation. The above regulation acts should be based on and use international experience and supranational level of cooperation and control. The economic process of capital outflow and its direct impact, volumes and consequences for international financial markets are considered. It is determined that the struggle for the competitiveness of the domestic financial market is one of the key motives that creates the scale and attractiveness of offshore centers, because of further manipulation and use of various schemes to minimize taxation and withdrawal of capital outside its origin. Statistical data indicates that such a significant concentration of funds in offshore jurisdictions accounts is a consequence of systematic tax evasion which leads to stable process of increasing international financial instability. It should be noted that the most tangible direct consequences of capital withdrawal, in addition to the lack of tax revenues by the budget are unfair tax competition; accumulation in offshore areas large amounts of speculative capital; growth of opportunities for shadowing of the economy and all the conditions for the direct outflow of capital from the country of origin. It is determined that nowadays the fundamental document in the field of. regulation international capital movements is Plan BEPS (Base erosion and profit shifting). This document defines the main stages and measures for countries to counter and control of the appearance new schemes which is aimed to aggressive tax optimization, profit shifting to offshores and generally globalization of the process of offshorization of financial markets and the economies of countries. Conclusions and suggestions are made that international cooperation and practical implementation of global recommendations (BEPS plan) can reduce the attractiveness of offshore financial centers and the further outflow of capital towards low-tax havens.

Key words: international financial center, financial markets, offshore jurisdiction, offshore zone, tax haven, BEPS plan, capital withdrawal, international competitiveness.

JEL classification: G15, F30, H26, F38, F53, G10 